\title{
Factor Reversal in the Euro Zone Stock Returns: Evidence from the Crisis Period*
}

\author{
Dr. Hsin I-Chou \\ Department of Finance \\ La Trobe University \\ Bundoora, VIC 3086 \\ Australia \\ E-mail: $\underline{\text { H.Chou@latrobe.edu.au }}$ \\ Dr. Jing Zhao \\ Department of Finance \\ La Trobe University \\ Bundoora, VIC 3086 \\ Australia \\ E-mail: J.Zhao@latrobe.edu.au \\ Associate Professor Sandy Suardi \\ (Corresponding author) \\ School of Economics \\ La Trobe University \\ Bundoora, VIC 3086 \\ Australia \\ E-mail: s.suardi@latrobe.edu.au \\ Tel: +6139479 2318 \\ Fax: +6139479 1654
}

\footnotetext{
* The authors would like to thank seminar participants at Nanyang Technological University, National Chengchi University, Lund University and Southern Denmark University. In particular, we thank Giovanni Ko, Zhou Jie, Hossein Ashgarian, Ole Bengtsson, Christian Dahl and Christian Ris Flor for useful comments, and Lu Liu and Hossein Ashgarian for sharing data on sovereign ratings. Any remaining errors are the responsibility of the authors.
} 


\begin{abstract}
The introduction of the common currency in the Euro zone has led to a shift in factor importance from country to industry effects. Nevertheless, there is overwhelming evidence that the recent spate of crises has engendered a reversal in factor importance, returning it to country effect. This factor reversal is caused by deteriorating macroeconomic fundamentals and institutional factor, and rising sovereign risks which were identified to play important roles in characterising country factor returns of the Euro zone member countries during the crisis. Moreover, fund managers who invested in Euro zone stocks during the crisis could have gained diversification benefits from the more traditional country portfolio approach.
\end{abstract}

Keywords: Euro equity markets; country effect; industry effect; portfolio diversification; crisis

JEL Classification: G11, G15 


\section{Introduction}

One of the critical issues international portfolio managers and investors must address is whether to focus their diversification efforts across countries or across industries. While a dearth of study (Griffin and Karolyi 1998; Bai and Green 2010) has shown that country effect continues to dominate industry effect, a consensus has emerged that industry effect has grown in importance relative to country effect since the late 1990s in developed markets (Baca et al. 2000, Cavaglia et al. 2000, Phylaktis and Xia, 2006) with similar evidence found in emerging Asian markets (Wang et al., 2003). The rising importance of industry effect in explaining equity markets comovements has been, in part, attributed to globalisation of the world economy and financial markets integration (Campa and Fernandes, 2006), and the dominant role played by information technology in the 1990s (Brooks and Del Negro 2006). In the Euro zone, the introduction of the euro currency has drawn considerable interest on inter-linkages between stock markets in Europe (Morana and Beltratti, 2002; Bartram et al., 2007; Mylonidis and Kollias 2010). Kim et al. (2005), in particular, find that the European stock markets have become more integrated after the EMU. Accordingly, the process of economic and financial integration in Europe has impacted the fundamentals of many economies in the Euro zone which give rise to the dominance of industry effect over country effect (Flavin 2004, Ferreira and Frreira 2006).

Theory suggests that given real and nominal convergence of economic structures in the Euro zone member countries and progressive reductions of differences in economic fundamentals that could induce different regional responses to global shocks, Euro zone equity returns would exhibit diminishing country effects. Furthermore, Griffin and Karolyi (1998) and Griffin and Stulz (2001) argue that industry-specific shocks may have a greater impact on industries which produce internationally traded goods. With greater trade being advocated as a benefit of the single currency

zone, it may therefore raise the sensitivity of certain stocks to industry-specific shocks, thus enhancing the role played by industry effect in explaining Euro zone stock returns. From the 
perspective of financial integration, an integrated financial market reflects no financial premium to industrial, sectoral or geographical diversification and better specialization is affordable. Financial integration, therefore, has the potential to change the mix of investment projects being financed and may open the way to a higher degree of industry specialization across countries. As this process of industry specialization takes place, industry effect is expected to dominate over country effect in characterising Euro zone equity returns.

There has been a plethora of empirical studies that attempt to validate the predicted increase in industry effect in the Euro area. The earliest study of Rouwenhorst (1999) which investigates the relative importance of country and industry effects in the European Monetary Union countries during the period 1993-1998 find that the former effect was larger than the latter despite the convergence of interest rates and the harmonization of fiscal and monetary policies following the Maastricht Treaty of 1992. Since then, studies by Flavin (2004) and Ferreira and Ferreira (2006) have documented an increasing importance of industry effect relative to country effect in the 1990s, with industry effect having a similar magnitude to country effect in the post-euro period. In particular, Ferreira and Ferreira (2006) show that the observed rising trend in industry effect is caused by nominal convergence in interest rates across EMU countries. Moerman (2008), using a mean-variance approach and utilising a longer data set spanning the period 1995-2004, find that a pure industry investment strategy contains better diversification opportunities than a pure country strategy during the euro period 1999-2004, thus supporting the view that industry effect has gained greater importance than country effect in the Euro area. A more recent study by Eiling, Gerard and De Roon (2011) find that there is a surge in importance of industry effect in the nine years after the introduction of the Euro. Their analysis shows that for the group of countries with the strongest preEuro linkages (Germany, France, the Netherlands, Belgium, Austria and Finland) industry effects have been dominant since 1990 but it has further strengthened following the introduction of the Euro. On the contrary, for the group of countries (Portugal, Italy, Ireland, Greece and Spain - also known 
as PIIGS) with the weakest pre-Euro linkages there has been a reversal in factor importance from country to industry effects after 1999.

The current paper goes beyond examining whether currency unification in the Euro zone, which is synonymous with full convergence of monetary policies, could have affected the equity pricing mechanism through the underlying (macro and micro) fundamentals of the economies. Unlike earlier studies, this paper further investigates whether these phenomena have continued in the recent period when a spate of financial crises has occurred. Despite extensive literature documenting an apparent increase in industry effect and the shift in factor importance from country to industry effects governing Euro zone equity returns, there are reasons to believe that the recent crises occurring from late 2007 to 2011, namely the Subprime crisis, global financial crisis and, in particular, the Euro debt crisis, are likely to exert an influence on the relative importance of country and industry effects driving the Euro zone stock returns.

A number of factors could explain this potential factor reversal from industry to country effects in the Euro zone equity returns during the crisis period. As put forward by Goetzmann, Li and Rouwenhorst (2002), financial market integration through its provision of an expanded investment opportunity set could give rise to greater cross-country correlation (particularly during the crisis period) and thus bring about a return to the importance of country effect. From the perspective of debt intolerance, which is the inability of many emerging market economies to handle overall debt levels that would seem quite manageable by the standards of the advanced industrial economies (Reinhart, Rogoff and Savastano, 2003), this implies that there is a tendency for Euro zone countries that are plagued with high levels of public debt to experience a higher level of country risk. Typically, these countries that suffer from debt intolerance have a history of economic mismanagement, which Reinhart et al. (2003) argue is the root cause of reduced debt bearing capacity. The description put forward by Reinhart et al. (2003) while it pertains to emerging markets equally applies and describes the current debt ridden Euro zone member countries like Greece and 
Italy well. In 1992, when members of the EU pledged to limit their deficit spending and debt levels by signing the Maastricht Treaty, a number of EU member states, including Greece and Italy, were able to circumvent these rules, failing to abide by their own internal guidelines, sidestepping best practice and ignoring internationally agreed standards. This allowed the sovereigns to mask their deficit and debt levels through a combination of techniques, including inconsistent accounting, offbalance-sheet transactions as well as the use of complex currency and credit derivatives structures. Since the adoption of the Euro, many Euro zone countries of different credit worthiness have received similar and very low interest rates for their bonds during years preceding the crisis (Abad et al., 2010). These ongoing institutional failings have, therefore, weakened the financial system and undermine tax-raising capacity and long-term growth of some of the Euro zone member countries.

Fundamentally, there is an inherent structural contradiction within the Euro system, that there is a monetary union without a fiscal union. While member countries in the Euro zone system are required to follow a similar fiscal path, they do not have a common treasury to enforce it nor are they able to regulate national financial institutions with ease, thus leading to member countries adopting diverse fiscal policies and eventually permitting fiscal free riding of peripheral economies, especially Greece. The absence of a clear cut solution to the current debt crisis and the policy conundrum to contain the crisis has led to greater uncertainty about the future sustainability of the Euro zone. Since membership of the Eurozone establishes a single monetary policy, individual member states are not able to act independently; they are unable to "print money" to pay creditors and ease their risk of default. By "printing money", a country's currency is devalued relative to its (Euro zone) trading partners, making its exports cheaper, in principle leading to an improved balance of trade, increased GDP and higher tax revenues in nominal terms. The ongoing Euro debt crisis has inadvertently raised the country risk profiles of the debt ridden economies and that of the other member countries, which could translate into increasing importance in country effect (and deteriorating country factor returns). This paper, therefore, seeks to determine whether there is a reversal in factor importance governing 
Euro zone stock returns in the crisis period, and if so can this reversal in factor returns be explained by macroeconomic fundamentals and institutional quality of the member countries.

The results of our empirical analysis provide evidence that industry effects have gained greater importance in characterising Euro zone equity returns in the post-Euro period before the onset of crises. These results support the myriad of arguments explaining the dominance of industry effects. However, in the post-Euro crisis period there is evidence of a fall in industry effect. Furthermore, in contrast to previous studies, there is overwhelming evidence of a significant shift in factor importance from industry back to country effects during, but not before, the crisis period. In fact, and being somewhat surprising, the shift back to country effects has dominated industry effects during the crisis period. A large proportion of the increase in country effect comes from PIIGS countries which are identified by Eiling et al. (2011) as the group of countries with the weakest preEuro linkages, and which we show they are the countries with the weakest macroeconomic fundamentals. This new evidence implies that the decline in country factor and the rise in industry factor documented previously in the literature are temporary phenomena. Evidence from the multiple structural break tests on the ratio of country to industry effect further support the presence of two breaks in the dynamic of country and industry factor importance in explaining Euro zone equity returns. The first break date coincides closely with the adoption of the euro in 1999 when country effect dominates industry effect in the pre-Euro period. The second break date occurs close to the date of the Subprime crisis and since then country effect has regained dominance over industry effect, which corroborates the notion of factor reversal in Euro zone equity returns. Given the importance of country effect over industry effect during the crisis period, fund managers should be careful about absolute adoption of industrial diversification strategies as suggested previously. This shift in factor importance bears pertinent implications on international portfolio diversification during a crisis period. Instead of focusing on the increased role for diversification across industrial sectors, it is equally prudent for fund managers to adopt country diversification strategy. We provide evidence that the rising importance of country effects is driven by deteriorating macroeconomic fundamentals 
including, amongst others, an increase in external debt to GDP ratio, a current account deficit and poor institutional quality in some of the Euro zone member economies.

The remainder of the paper is organised as follows. Section 2 describes the data sample and Section 3 presents the methodology. Section 4 contains the empirical results. Section 5 offers a conclusion.

\section{Data}

Unlike previous studies like Flavin (2004) and Ferreira and Ferreira (2006), our study uses a larger dataset covering three times the number of companies examined by Flavin (2004) and a longer span of time series data comprising more than a decade of post-Euro data. This period is unique, in that it covers the subprime crisis, the global financial crisis and the sovereign debt crisis, and thereby provides a natural experiment to assess the implications of crisis on the relative importance of country and industry effects on the Euro zone stock returns. The sample, which is obtained from Datastream, comprises monthly total returns and market capitalisations on 3406 companies across the 12 members of the Euro zone from September 1992 to September 2011. ${ }^{1}$ To address the question whether the crises engender a different response in factors importance of stock returns in Euro zone, we also undertake a similar analysis on a control group made up of the UK, Switzerland, Denmark and Sweden which lie outside the single currency area. All returns are denominated in Euro. Pre-Euro and post-Euro returns for the non-EU countries are computed by converting from the domestic currency to the Euro using the ECU end-of-month exchange rate. Each company is assigned to an industrial sector and a country according to the Datastream classification, which is consistent with the

\footnotetext{
${ }^{1}$ In 1998 eleven European Union member states had met the convergence criterion, and the Euro zone came into existence with the official launch of the Euro (alongside national currencies) on 1 January 1999. Greece did not qualify until January 2001.
} 
FTSE/JSE global classification system. There are ten broad industrial classifications. ${ }^{2}$ Table $^{1}$ reports the industrial and geographical breakdown of these companies. It is evident that companies are not distributed uniformly across industrial sectors as well as across countries. The Luxembourg has the lowest number of stocks. On the other hand, Germany has the highest number of stocks with a high concentration in financial industry amongst the Euro zone member countries.

\section{- Table 1 about here -}

\section{Methodology}

To ensure comparability of our results with earlier studies of Flavin (2004) and Ferreira and Ferreira (2006), we follow the model proposed by Heston and Rouwenhorst (1994) in which equity return is driven by industry, country and global (Euro area) factors. Specifically, the return of any stock $i$ that belongs to industry $j$ and country $k$ is given by:

$R_{i t}=\alpha_{t}+\beta_{j t}+\gamma_{k t}+\varepsilon_{i t}$

where $\alpha_{t}$ denotes the common (or global) component of all stocks, $\beta_{j t}$ measures the industry effect and $\gamma_{k t}$ measures the country effect. The error term $\varepsilon_{i t}$ is asset specific and is assumed to have zero mean and a finite variance. The model represented by equation (1) although somewhat restrictive, provides a tractable representation of economic reality. Underlying this representation is the assumption that securities in the same country have similar exposures to domestic and global factors which may be unrealistic since companies' proportions of foreign sales to total sales indicate that companies have different exposures to factors other than the specific country for which these companies are located. This criticism is particularly true for listed multinationals. Notwithstanding

\footnotetext{
${ }^{2}$ The use of broad industrial classifications is consistent with other studies (see Flavin [2004]; Ferreira and Frreira [2006]). Griffin and Karolyi (1998) demonstrate that using very fine industry definitions give rise to qualitatively similar results as that of broad industry classifications.
} 
the drawback of Heston and Rouwenhorst's (1994) methodology, as highlighted by Brooks and Del Negro (2002), this approach is widely used by empirical researchers. On this note, it is important to qualify that the results of our analysis are conditioned on the extent to which our estimates of the country and industry factors are independent of company characteristics and the extent to which our simplifying assumptions provide a sufficiently close representation of economic phenomena.

The framework in equation (1) helps in determining the relative importance of country and industry factors in driving security returns. These factors returns are "unobservable” but can be estimated from the "observable” excess returns on securities. For each month in the sample, we estimate the parameters on the right-hand-side of equation (1) by running a cross-sectional regression of the returns of all firms in our sample with a set of industry and country dummies:

$$
R_{i}=\alpha+\beta_{1} I_{i 1}+\beta_{2} I_{i 2}+\cdots+\beta_{J} I_{i J}+\gamma_{1} C_{i 1}+\gamma_{2} C_{i 2}+\cdots+\gamma_{K} C_{i K}+\varepsilon_{i t}
$$

where $I_{i j}=1$ if firm $i$ belongs to industry $j$ and zero otherwise, and $C_{i k}=1$ if firm $i$ belongs to country $k$ and zero otherwise.

Since equation (2) cannot be estimated due to perfect multicollinearity, one way of getting around this problem is to attach weights to the industries and countries by the proportion of the total Euro zone market that they account for, which amounts to measuring them relative to a valueweighted portfolio of stocks. In other words,

$\sum_{j=1}^{10} w_{j} \beta_{j}=0$ and $\sum_{k=1}^{12} v_{k} \gamma_{k}=0$

where $w_{j}$ and $v_{k}$ are the weights of industry $j$ and country $k$ in the Euro zone market portfolio, respectively. Estimation of (2) and (3) give rise to $\beta_{j}$ and $\gamma_{k}$ series. As Heston and Rouwenhorst (1995) argued, $\beta_{j, t}$ can be interpreted as the return in excess of benchmark at time $t$ from a tilt in 
global industry $j$ with neutral country exposure, while $\gamma_{k, t}$ can be interpreted as the return in excess of benchmark at time $t$ from a tilt in country $k$ with neutral industry exposure.

The $\beta_{j}$ and $\gamma_{k}$ series can then be used to assess the role of the common and the industry factors in country returns,

$R_{k}=\hat{\alpha}+\sum_{j=1}^{10} w_{j}^{k} \hat{\beta}_{j} I_{k j}+\hat{\gamma}_{k}$

where $R_{k}$ is country $k$ index return and $w_{j}^{k}$ is the share of industry $j$ in the total market capitalization of country $k$. Similarly, the role of the common and country factors in industry returns is given by

$R_{j}=\hat{\alpha}+\sum_{k=1}^{12} v_{j}^{k} \hat{\gamma}_{k} C_{j k}+\hat{\beta}_{j}$

where $R_{j}$ is industry $j$ index return and $v_{j}^{k}$ is the share of country $k$ in the total market capitalization of industry $j$. Accordingly, we can decompose the country return $R_{k}$ into a component common to all countries, $\hat{\alpha}$, the weighted average of the industry effects that compose country $k$ index, and a pure country component, $\hat{\gamma}_{k}$. Likewise industry return $R_{j}$ can be decomposed into a component common to all countries, $\hat{\alpha}$, the weighted average of the country effects that compose industry $j$ index, and a pure industry component, $\hat{\beta}_{j}$. ${ }^{3}$ For robustness check, we also performed the analysis using equally weighted market portfolios. The results are qualitatively similar to the value weighted findings. We do not present the results here for brevity but they are available from the authors upon request.

\section{Empirical Results}

\footnotetext{
${ }^{3}$ We also performed robustness analysis using an equal weighting and the results are qualitatively unchanged. Hence, we only report the results for the value weighted approach.
} 


\subsection{Relative size of country and industry effects}

Table 2 provides the mean and standard deviation of the industry and country effects in percentage per month for both Euro zone and non-Euro zone countries across three periods. The first sample denotes the pre-Euro period while the second and third samples cover the post-Euro before and during crisis periods. Consider the first row of the table which shows that the average portfolio of stocks in basic materials industry with the same country composition as the Euro zone index underperformed the Euro zone index by $0.44 \%$ per month (or $5.28 \%$ per year) with a standard deviation of $1.72 \%$ per month. A striking feature of Table 2 is that the absolute value of the country effects prior to the adoption of the Euro is on average larger than the absolute value of the industry effects. This is consistent with the findings of Heston and Rouwenhorst (1995) who investigate an earlier period for 1978-1992. It is interesting to note that the standard deviation of the industry effects in oil and gas, technology, telecommunication and utilities are of a higher order in magnitude than the other industries. These industries are typically more risky involving a large capital outlay and so not surprisingly their stock returns exhibit higher variance.

We compute the average absolute country and industry effects in each sample period as

$\frac{1}{T} \sum_{t=1}^{T} \sum_{k=1}^{12} v_{k, t}\left|\gamma_{k, t}\right|$ and $\frac{1}{T} \sum_{t=1}^{T} \sum_{j=1}^{10} w_{j, t}\left|\beta_{j, t}\right|$ respectively, due to restrictions (3). Looking at the average absolute value of the industry effects across the three periods in Euro zone countries, there is evidence that the size of industry effect has increased from $1.36 \%$ to $2.65 \%$ since the adoption of a single currency. The average absolute value of the country effect, on the other hand, has decreased from $1.65 \%$ to $1.53 \%$ since the establishment of the Euro zone. This apparent shift in factor importance from country to industry effect is consistent with the widely documented industry effect dominance in the literature. However, during the crisis period, there has been a significant drop in industry effect from $2.65 \%$ to $1.92 \%$ followed with a dramatic increase in the average absolute value of the country effect from $1.53 \%$ to $2.16 \%$ and its magnitude surpasses that of the industry effect. The observed reversal in factor importance from industry to country effect is never previously 
documented in the literature. It does confirm Flavin's (2004) prediction that "the decline in country factors may be temporary”.

When we further analysed the contributing countries that give rise to this factor reversal, we found that, in large part, the group of PIIGS countries was the major contributor of the change in the relative importance of factor dynamics. During the crisis period, PIIGS countries observe a drastic fall in the average absolute value of industry effect falling by about $0.88 \%$ per month $(10.6 \%$ per annum) compared to the non-PIIGS countries which only fell by $0.55 \%$. As for the rise in country effect during the crisis period, we also find that the PIIGS countries experience an increase of about $0.4 \%$ per month ( $4.8 \%$ per year) compared to only about $0.3 \%$ for the non-PIIGS counterpart. Together, these changes to country and industry factor returns give rise to the observed factor reversal from industry to country effect during the crisis period.

We also identify an interesting pattern in the relative factor importance between country and industry effects which drive the Euro zone stock returns. In the period pre- and post-Euro before the crisis (i.e. 1992-2007), we obtain similar findings as that of Eiling et al. (2011) who investigate for the period 1990-2008. There is evidence that in the pre-Euro period the PIIGS countries (with an average absolute value of 3.52\%) exhibit greater country effect than the group of countries with the strongest pre-Euro linkages (which has an average absolute value of 1.27\%). However, following the adoption of the euro, there is a significant decrease in the average absolute value of the country effect for the PIIGS countries, falling by about seventeen times more than the fall observed in non-PIIGS countries. As for the increase in industry effect across both PIIGS and non-PIIGS countries, they both increase by about the same magnitude, $1.2 \%$. These results are consistent with the view that the PIIGS countries started the sample period not being highly integrated within the Euro-zone, and as a result of the convergence process during the transition to the Euro, they became substantially integrated within the Euro-zone thereby experiencing a sharper fall in the country effect. 


\section{- Table 2 about here -}

To determine whether this factor reversal is unique to the Euro zone countries, we turn to the results of the non-Euro zone countries. Since the emergence of the Euro zone, there has been an increase in the average absolute value of industry effect from $1.81 \%$ to $2.14 \%$. While we may have observed an increase in industry effect, in terms of magnitude, this is of the order one quarter of that experienced by the EU countries. Given the results of the control group, it can be inferred that the formation of the Euro zone which undergirds greater political and economic integration has indeed led to an increased importance in industry effect amongst Euro zone countries. During the crisis period, there is a negligible increase $(0.01 \%)$ in the size of industry effect in non-Euro zone countries. In contrast, the country effect has increased significantly from $1.11 \%$ pre-crisis to $1.87 \%$ during the crisis. This result can be rationalised by an increase in stock market volatility during crisis period which, in turn, contributes to an increase in the magnitude of country effects observed in the turbulent last sample period. However, the increase in country effect did not cause its level to surpass that of industry effect. Taken together, the observed pattern of factor reversal from industry to country effects can be interpreted as being limited to the Euro zone and did not take place in the wider non-Euro area.

Finally, it is interesting to note that the mean country effects for countries that are beset by the debt crisis are significantly and highly negative. For instance, Greece has the lowest country effect of $-2.65 \%$, followed by Italy (-1.51\%), Spain (-1.46\%) and Portugal $(-1.32 \%)$. To put this number into perspective, suppose $10 \%$ of the stocks in the Euro zone index portfolio is replaced with Greece stocks during the investment period 2008 to 2011, while holding the industry composition of the portfolio unchanged, this would lead to underperformance of the benchmark by $10 \% \times 2.65=0.265 \%$ per month, with a standard deviation of the tracking error of $10 \% \times 5.4=0.54 \%$ per month.

\subsection{Evolution of country and industry effects over time}


We followed the literature in computing the time series variance of the components resulting from the decomposition of country (industry) returns into a common factor, a pure country (industry) factor and an average of the industry (country) factors for the value-weighted Euro zone equity market. In Table 3, Panel A presents the results for each country, Panel B for each industry, and Panel C presents averages across country and industry as well as the common factor.

\section{- Table 3 about here -}

It can be seen that since the adoption of the Euro, the country effect has lost dominance over the industry and common market effects. The reduction in average variances of the Euro-area pure country effects across the three samples, from 3.49\%-squared to $2.98 \%$-squared, is also indicative that the Euro-area business cycles have become more synchronised. Note that this pattern is not observed for the variances of the non-Euro area pure country effects. However, during the crisis period, the average variance of both pure country and pure industry effects has fallen to $2.98 \%$ squared and 4.00\%-squared, respectively, although the fall in pure industry effect is larger than the fall in pure country effect. Accordingly, this has given rise to an increase in the ratio of pure country to industry effects during the crisis period. In other words, if the variability of industry effects has fallen by more than the fall in variability of country effect, then more risk reduction will be achieved by diversifying across countries than by diversifying across industries. This prediction concurs with our findings to portfolio diversification discussed in Section 4.3. The Euro effect captured by the common market factor has also played a more important role over time. The average variances of the Euro-area (or common market) effect has increased gradually from 3.40\%-squared in pre-Euro period to $4.89 \%$-squared in post-Euro period, and increasing further to 5.88\%-squared in the post-Euro crisis period. The fact that the average variances of the common market effect are larger than the country effect, and the ratio of pure country to common effects has fallen further in the crisis period suggest that there is increasing integration of the capital markets in Euro area since the adoption of the euro. 
The pure industry effect variances display large variation across the industries. Notably, from 1999 to 2007, technology and telecommunication stocks show the largest industry effects variance. However, following the burst of the dotcom bubble in 2001, the variance of technology stocks has fallen to a level comparable with other industries. Nonetheless, the variance of industry effects in telecommunication and utilities stocks remain larger than the industry average in the period 20082011. This pattern is equally observed in the non-Euro area. A possible explanation for these empirical observation is that utilities and telecommunication stocks are non-cyclical (or defensive) stocks and they tend to do well in economic downturns, particularly when demand for their products and services continues regardless of the state of the economy.

\section{- Figure 1 about here -}

Figure 1 plots the ratio of the six-month moving average of the monthly country and industry mean absolute deviation (MAD) metric that is proposed by Rouwenhorst (1999). Specifically, the country and industry MAD can be written as $M A D_{C}=\sum_{k=1}^{12} v_{k}\left|\gamma_{k}\right|$, and $M A D_{I}=\sum_{j=1}^{10} w_{j}\left|\beta_{j}\right|$, where $\beta_{j}$ measures the industry effect, $\gamma_{k}$ measures the country effect, and $w_{j}$ and $v_{k}$ are the weights of industry $j$ and country $k$ in the Euro zone market portfolio, respectively. The importance of each factor (country versus industry) can be easily inferred from this ratio. It can be seen that in 19921998, the MAD ratio tends to be larger than one implying the dominance of country effect over industry effect. However, in the subsequent period 1999-2007, the ratio of the MAD largely falls below one supporting the view that there has been a shift in factor importance from country to industry effects. Interestingly, since October 2007 the start of the subprime crisis, the MAD ratio has begun to increase gradually and has remained largely close to or above one. This suggests that in the period ridden with crises there has been a reversal in factor importance with the country effect gaining greater, if not equal, importance as the industry effect. The apparent dip in the MAD ratio around about October 2009 is driven by the superior performance of telecommunication and utilities 
stocks which outperform the European Monetary Union market index. The telecommunication and utilities industries are regarded as defensive stocks since the worst Euro zone market performance in 2009.

Without solely relying on visual evidence of the time series plot of the MAD ratio to justify the alleged factor reversal from industry to country effects, we perform a structural break test based on the approach suggested by Bai and Perron $(1998,2003)$ on the mean of the MAD ratio. In what follows we adhere to the practical recommendations made by Bai and Perron (2003). ${ }^{4}$ We start by computing the double maximum test statistics $U D_{\max } F_{T}(M, q)$ and $W D_{\max } F_{T}(M, q)$. These two tests have the null hypothesis of no structural break against an unknown number of breaks given some upper bound $M$. Here, $q$ denotes the dimension of the covariate vector that is permitted to vary in its parameter. In our case given that we are only interested in structural changes in the mean, this implies $q=1$. The $U D_{\text {max }} F_{T}(M, q)$ test applies equal weights to the individual tests while the $W D_{\max } F_{T}(M, q)$ test applies different weights to the individual tests such that the marginal p-values are equal across the number of breaks, $m$ for $1 \leq m \leq M .^{5}$ The break points are obtained using the BIC as Bai and Perron (2003) argue that the AIC usually overestimate the number of breaks and that the BIC is suitable selection procedure in many situations. Conditional on both test statistics being significant at the 5\% level, which indicates the presence of at least one break, we then decide on the number of breaks by sequentially examining the sup $-F(l+1 \mid l)$ test statistics starting from $l=1$. We also set the maximum number of structural changes to $M=4$. The results are reported in Table 4. A detailed discussion of the analytical framework for double maximum tests and the sequential structural break test is provided in the Appendix.

\section{- Table 4 and Figure 2 about here -}

\footnotetext{
${ }^{4}$ See Section 5.5 on 'Summary and Practical Recommendations' in Bai and Perron (2003). This approach is adopted by Mylonidis and Kollias (2010) in estimating and testing for structural changes in European stock market in frist Eurodecade.

${ }^{5}$ For details on the application of weights to the individual tests in $W D_{\max } F_{T}(M, q)$ see Bai and Perron (1998).
} 
The double maximum test statistics $U D_{\max } F_{T}(M, q)$ and $W D_{\max } F_{T}(M, q)$ overwhelmingly reject the null hypothesis of no structural break at the $5 \%$ significance level and suggest the presence of some unknown number of structural breaks given an upper bound of 4 breaks. ${ }^{6}$ The BIC indicates the presence of two breaks as does the $\sup -F(l+1 \mid l)$ test statistics. The first structural break date is identified to be in August 1998 which is close to the start of the adoption of the euro, and the second break date is in September 2007 which is closely associated with the start of the Subprime crisis. The estimated mean of the MAD ratio in the three sample periods, which are all statistically significant at the 1\% significance level, are 1.42 in the pre-Euro period (1992:3 - 1998:8), 0.84 in the post-Euro period prior to the start of the Subprime crisis (1998:9 - 2007:9) and 1.14 in the post-Euro and crisis period (2007:10 - 2011:9). Importantly, the average of the MAD ratio for the last two periods supports our hypothesis on factor reversal from industry effect to country effect during the crisis period. Figure 2 provides a visual impression of the structural break dates and the time-varying average MAD ratio across the sample period. For robustness, we performed a similar analysis using the noisier monthly MAD ratio series and the results support the presence of two structural breaks with the dates coinciding close to the dates identified for the 6-month moving average MAD ratio. These results are not presented here for brevity but are available from the authors upon request.

\subsection{What drives the rising importance in country effects?}

We investigate the sources of this observed factor reversal underlying Euro zone equity returns by studying the linkages between macroeconomic fundamentals, institutional quality and country effect. To that end we estimate the following fixed effect panel regression over 2000-2011 for quarterly data. This period is chosen as data for Debt/GDP ratio are only available from 2000 onwards.

\footnotetext{
${ }^{6}$ We compare the test statistics with critical values obtained from bootstrapped procedure as the structural break test is performed on an estimated series thus the underlying distribution of the UDmax and WDmax test statistics would be affected by parameter estimation uncertainty and the critical values reported in Bai and Perron $(1998,2003)$ may not apply. The bootstrapped critical values at the 5\% level are 9.15 and 10.38 for UDmax and WDmax tests, respectively.
} 


$$
\begin{aligned}
\gamma_{k t}=\beta_{0}+\beta_{1} D 2 & +D 1\left(\beta_{11} \text { debt }_{k t}+\beta_{21} \text { Inf }_{k t}+\beta_{31} C_{k t}+\beta_{41} G D P_{k t}+\beta_{51} \text { Corr }_{k t}\right. \\
& \left.+\beta_{61} \text { SyrBond }_{k t}+\beta_{71} S \& P 500+\beta_{81} \text { Fitch }\right) \\
& +D 2\left(\beta_{12} \text { debt }_{k t}+\beta_{22} \text { Inf }_{k t}+\beta_{32} C_{k t}+\beta_{42} G D P_{k t}+\beta_{52} \text { Corr }_{k t}+\beta_{62} 5 y r B o n d_{k t}\right. \\
& \left.+\beta_{72} S \& P 500+\beta_{82} \text { Fitch }\right)+u_{k}+e_{i t}
\end{aligned}
$$

where $d e b t_{k t}$ denotes debt to GDP ratio, $\operatorname{In} f_{k t}$ denotes annual inflation rates, $C A_{k t}$ denotes current account to GDP ratio, $G D P_{k t}$ denotes real GDP growth rates, $\operatorname{Corr}_{k t}$ denotes corruption index and 5yrBond $_{k t}$ denotes 5-year government bond yield. Here, $\gamma_{k t}$ is country effect for country $k$ in period (or quarter) $t$ while D1 (D2) denotes an indicator dummy which equals 1 if $t=2000$-2007 (20082011) and 0 for $t=2008$-2011 (2000-2007). Interactive terms are introduced between the regressors and the two dummies as we are interested in capturing the manner by which macroeconomic fundamentals determine country effect before and during the crisis period. For the most part, many of the regressors reflect macroeconomic factors, except for corruption index which captures deep institutional factor, and the two country sovereign ratings from S\&P500 and Fitch. ${ }^{7}$ The data for all macroeconomic variables except for debt to GDP ratio are taken from International Financial Statistics database. Debt to GDP ratio data are obtained from EuroStat database, while the corruption index is obtained from Transparency International. Sovereign ratings data are obtained from S\&P500 and Fitch database.

\section{- Table 5 about here -}

Table 5 provides a summary statistics of the regressors. It is apparent that Euro zone has a higher debt to GDP ratio compared to non-Euro countries. Apart from external debt, Euro area countries on average also experienced current account deficit compared to their non-Euro counterparts. The higher debt to GDP ratio and the current account deficit are dominated by the relatively inferior

\footnotetext{
${ }^{7}$ In the regression analysis, ratings of Fitch are recorded numerically with AAA equals to 18, AA+ equals to 17, and so on until CCC which equals 1 . Ratings of S\&P500 are recorded numerically with AAA equals to 12, AA+ equals to 11, and so on until $\mathrm{C}$ which equals 1.
} 
macroeconomic performance of the PIIGS countries compared to the non-PIIGS counterparts. While the corruption index of the Euro countries are bordering the non-Euro, an examination of the PIIGS corruption index reveals that these countries suffer from lower institutional quality compared to the non-PIIGS. The GDP growth rates, level of inflation, and the 5-year government bond yield are more or less comparable between Euro and non-Euro countries. Prior to the crisis in sample (II), the average PIIGS countries enjoyed a similar cost of financing like the non-PIIGS as judged by the 5year government bond rates. However, during the crisis period, there is a significant divergent in the bond rates between PIIGS and non-PIIGS. Moreover, for the PIIGS countries the current account to GDP ratio has fallen further while debt to GDP ratio has ballooned drastically from $72 \%$ to $91 \%$. Not surprisingly, the real GDP growth rates of both PIIGS and non-PIIGS have also fallen during the crisis period. Panel B of Table 5 shows the correlation matrix of these macroeconomic variables and country effect. The second column shows that the correlation coefficients between country effect and macroeconomic variables have the anticipated and correct signs. Given that we have an extensive number of macroeconomic variables, it is highly likely that there would be problem of multicollinearity in the panel regressions. For instance, we observe that debt/GDP ratio is strongly and statistically correlated with CA/GDP, corruption and 5-year government bond yield. The two sovereign ratings are also highly correlated with the corruption index, 5-year government bond yields, CA/GDP and debt/GDP. To mitigate the problem of multicollinearity, we estimate the regression for combinations of the right-hand side variables.

\section{- Table 6 about here -}

It can be seen in Table 6 from regressions (1) to (8) that many of the explanatory variables are statistically significant except for real GDP growth and inflation. Interestingly, these macroeconomic determinants have little explanatory power prior to the crisis period, but they explain variations in the country effects in the Euro area during the crisis period. For example, an increase in debt/GDP ratio by $10 \%$ would reduce country factor return by about $0.2 \%$ per quarter (or $0.8 \%$ per annum) during 
the crisis period. The time dummy D2 is also statistically significant implying that there is a level shift in country factor return by as large as $-6.52 \%$ in regression (8) during the crisis period. Due to the observed multicollinearity problem in some of the regressors, we perform four separate grand regressions involving combinations of the macroeconomic variables; these are reported in regressions (9) to (12). It can be seen that the coefficient of the crisis period dummy, D2, is statistically significant and the coefficient has a negative sign implying that during the crisis, the average level of country factor returns has fallen. The macroeconomic variable which possesses significant explanatory power in characterising country factor returns is the 5-year government bond rate. In all three grand regressions (9) to (11), the coefficient is only statistically significant and negative during the crisis period thereby suggesting that a $1 \%$ rise in bond yield per quarter is associated with a fall in country factor return by about $0.8 \%$ per annum, ceteris paribus. Other variables like CA/GDP, corruption index and the Fitch country sovereign ratings also explain movements in country factor returns during the crisis period. Taken together, the observed factor reversal driven by a more dominant country factor relative to industry factor during the crisis can be attributed to the weak macroeconomic fundamentals, institutional factor and rising sovereign risks associated with the Euro zone member countries.

\subsection{Implications for international diversification}

To understand the implications of factor reversal from industry to country effects on international diversification in the Euro zone during the crisis period, we calculate the risk reduction that can be achieved through alternative diversification strategies (country or industry) relative to the average asset (national industry portfolios) variance-diversification ratio. A country (industry) strategy involves diversifying across countries (industries) within a specific industry (country). The unrestricted strategy involves diversifying both over countries as well as over industries. The diversification ratio for the alternative strategies is given by the portfolio variance relative to the average asset variance using equal weights: 
$\frac{\operatorname{Var}\left(\sum_{i=1}^{N} R_{i}\right)}{\frac{1}{N} \sum_{i=1}^{N} \operatorname{Var}\left(R_{i}\right)}=\frac{1}{N}+\left(\frac{N-1}{N}\right) \frac{\overline{\operatorname{Cov}\left(R_{l}, R_{S}\right)}}{\overline{\operatorname{Var}\left(R_{l}\right)}}$

where $N$ denotes the number of stocks and the upper bar indicates averages. ${ }^{8}$

\section{- Figure 3 about here -}

Figure 3 demonstrates the benefits of international diversification against number of assets. In the pre-Euro period, the strategy that diversifies across countries in an industry reduces portfolio variance to $17.7 \%$ of the average asset variance. Industry diversification in a single country, on the other hand, reduces the portfolio variance by $21.6 \%$. The reduction in portfolio variance by the unrestricted strategy is $11.4 \%$. In the post-Euro period before the crisis, the shift in factor importance to industry effect is evident from the greater reduction in portfolio variance under the industry strategy relative to country strategy. However, during the crisis period, it can be seen that the dominance of industry effect over country effect has significantly diminished. In fact, the reduction in portfolio variance from adopting country strategy is more or less the same as that of industry strategy. This result suggests when investing in Euro zone equity markets during the crisis period, the

\footnotetext{
${ }^{8}$ Heston and Rouwenhorst (1994) provide an elaboration on the plot of risk diversification (see footnote 5 on page 20) for which we follow their methodology. For the pre-Euro period, the average stock return has a variance of 0.0164 per month. An equally-weighted portfolio of $\mathrm{N}$ stocks has a variance equal to $0.0164 / \mathrm{N}$ plus $(\mathrm{N}-1) / \mathrm{N}$ times the average covariance among these stocks. The average covariance in a large group of stocks is equal to the variance of an equallyweighted index. When diversifying across all stocks in the Euro zone, the average covariance is 0.0011 . The variance of the equally-weighted Euro zone index is only $6.7 \%$ of the average variance of an individual stock. The weighted average variance of equally-weighted indices across countries is 0.0029 , and the weighted average variance of equally-weighted indices across industries is 0.0022 . These weighted averages are $17.6 \%$ and $13.4 \%$ of the average security variance, respectively. For the pre-crisis (crisis) period, the average stock return has a variance of 0.0137 (0.0522) per month, the variance of the equally-weighted Euro zone index is 0.0021 (0.0030), the weighted average variance of equally-weighted indices across countries is 0.0026 (0.0041), while the weighted average variance of equally-weighted indices across industries is $0.0039(0.0048)$.
} 
more traditional country portfolio approach could serve as effective a tool for achieving risk reduction as industry diversification.

\section{Summary and conclusions}

The main purpose of this paper is to examine the historical and recent evolution of the industry versus country effects in the Euro zone equity markets, particularly in light of the recent spate of financial crises. The process of financial and economic integration in Europe is manifest through significant changes in the fundamentals underlying equity markets. There seems to have been a long-run evolution alleged to be consistent with a narrowing of the superiority of country effects and a shift towards the superiority of industry diversification. However, we show for the first time that, with the onset of crises, this shift in factor importance was short-lived. There is evidence that since late 2007 country effect has gained greater importance in explaining Euro zone equity returns and that the traditional approach of country diversification would achieve as good a risk reduction as industry diversification. This observed factor reversal from industry and to country effect is driven by the rise (fall) in country (industry) effect emanating from PIIGS and non-PIIGS countries during the crisis period. We also document evidence that the rise in country effect during the crisis period is largely driven by poor macroeconomic fundamentals, weak institutional quality and sovereign risks prevalent in some of the Euro zone member countries. 
Table 1 Number of firms by country and industry

\begin{tabular}{|c|c|c|c|c|c|c|c|c|c|c|c|}
\hline & $\mathrm{BM}$ & CG & CS & FI & $\mathrm{HC}$ & IN & OG & TEC & TEL & UT & TOTAL \\
\hline \multicolumn{12}{|c|}{ Panel A: Number of stocks by industry and country in balanced Euro zone } \\
\hline Austria & 6 & 16 & 4 & 30 & 3 & 25 & 3 & 7 & 1 & 4 & 99 \\
\hline Belgium & 8 & 22 & 19 & 61 & 14 & 32 & 4 & 16 & 2 & 4 & 182 \\
\hline Finland & 10 & 14 & 12 & 13 & 5 & 41 & 1 & 24 & 1 & 1 & 122 \\
\hline France & 28 & 134 & 142 & 142 & 55 & 165 & 19 & 101 & 8 & 22 & 816 \\
\hline Germany & 63 & 130 & 141 & 352 & 66 & 205 & 47 & 164 & 11 & 23 & 1202 \\
\hline Greece & 24 & 67 & 39 & 34 & 10 & 57 & 2 & 24 & 1 & 4 & 262 \\
\hline Ireland & 7 & 8 & 9 & 9 & 5 & 9 & 6 & 2 & 1 & 0 & 56 \\
\hline Italy & 5 & 51 & 33 & 66 & 10 & 62 & 7 & 20 & 4 & 18 & 276 \\
\hline Luxembourg & 3 & 7 & 5 & 24 & 0 & 3 & 3 & 0 & 2 & 1 & 48 \\
\hline Netherland & 7 & 15 & 18 & 24 & 7 & 34 & 5 & 20 & 1 & 1 & 132 \\
\hline Portugal & 7 & 8 & 15 & 5 & 1 & 14 & 1 & 4 & 2 & 2 & 59 \\
\hline Spain & 14 & 16 & 14 & 50 & 10 & 29 & 4 & 4 & 3 & 8 & 152 \\
\hline Euro zone & 182 & 488 & 451 & 810 & 186 & 676 & 102 & 386 & 37 & 88 & 3406 \\
\hline \multicolumn{12}{|c|}{ Panel B: Number of stocks by industry and country in non-Euro zone } \\
\hline Denmark & 3 & 17 & 15 & 66 & 20 & 35 & 3 & 9 & 2 & 2 & 172 \\
\hline Sweden & 36 & 40 & 60 & 57 & 68 & 118 & 14 & 69 & 7 & 4 & 473 \\
\hline Switzerland & 20 & 30 & 27 & 112 & 31 & 65 & 5 & 21 & 1 & 13 & 325 \\
\hline UK & 179 & 111 & 260 & 367 & 98 & 364 & 135 & 158 & 19 & 24 & 1715 \\
\hline non-Euro zone & 238 & 198 & 362 & 602 & 217 & 582 & 157 & 257 & 29 & 43 & 2685 \\
\hline
\end{tabular}


Table 2 Industry and Country Effects -Value Weighted

\begin{tabular}{|c|c|c|c|c|c|c|}
\hline \multirow{2}{*}{$\begin{array}{l}\text { Panel A: Euro countries } \\
\text { Industry Effects }\end{array}$} & \multicolumn{2}{|c|}{ 1992:9 -1998:12 } & \multicolumn{2}{|c|}{ 1999:1-2007:12 } & \multicolumn{2}{|c|}{ 2008:1-2011:9 } \\
\hline & Mean & SD & Mean & SD & Mean & SD \\
\hline Basic Materials & -0.44 & 1.72 & -0.1 & 3.3 & 0.27 & 2.93 \\
\hline Consumer Goods & -0.32 & 1.03 & -0.52 & 3.49 & 0.42 & 2.12 \\
\hline Consumer Services & -0.09 & 1.2 & -0.54 & 2.4 & 0.49 & 2.37 \\
\hline Financials & -0.08 & 1.14 & -0.3 & 2.9 & -0.4 & 1.51 \\
\hline Health Care & -0.33 & 1.4 & -0.27 & 2.8 & 0.08 & 1.51 \\
\hline Industrials & 0.15 & 2.12 & 0.06 & 3.57 & -0.94 & 1.87 \\
\hline Oil \& Gas & 0.2 & 5.08 & 0.8 & 4.53 & -1.57 & 3.14 \\
\hline Technology & 1.07 & 3.37 & -0.58 & 5.66 & 0.38 & 2.34 \\
\hline Telecommunications & 0.62 & 4.19 & -0.57 & 6.77 & 1.91 & 7.19 \\
\hline Utilities & -0.12 & 2.4 & -0.01 & 3.63 & 0.71 & 5.12 \\
\hline Average absolute industry effect & 1.36 & & 2.65 & & 1.92 & \\
\hline PIIGS countries & 1.51 & & 2.74 & & 1.86 & \\
\hline Non-PIIGS EMU countries & 1.33 & & 2.62 & & 2.07 & \\
\hline Country Effects & Mean & SD & Mean & SD & Mean & SD \\
\hline Austria & -0.84 & 3.15 & -0.18 & 2.39 & -0.25 & 2.29 \\
\hline Belgium & 0.29 & 1.96 & -0.58 & 2.75 & -0.13 & 2.26 \\
\hline Finland & 1.36 & 5.98 & 0.18 & 3.71 & -0.65 & 2.77 \\
\hline France & -0.06 & 1.6 & 0.75 & 1.69 & 0.37 & 1.63 \\
\hline Germany & -0.41 & 1.54 & -0.37 & 2.03 & 1.35 & 2.33 \\
\hline Greece & 1.31 & 5.9 & -0.44 & 7.92 & -2.65 & 5.4 \\
\hline Ireland & 1.07 & 3.64 & 0.31 & 3.21 & -0.51 & 5.51 \\
\hline Italy & 0.04 & 5.43 & -0.31 & 2.83 & -1.51 & 2.01 \\
\hline Luxemburg & 0.34 & 2.56 & -0.71 & 3.15 & -0.01 & 2.91 \\
\hline Netherland & 0.45 & 1.69 & -0.35 & 1.95 & 0.22 & 2.94 \\
\hline Portugal & 0.62 & 3.94 & -0.05 & 4.11 & -1.32 & 3.49 \\
\hline Spain & 0.79 & 4.46 & -0.08 & 2.69 & -1.46 & 2.21 \\
\hline Average absolute country effect & 1.65 & & 1.53 & & 2.16 & \\
\hline PIIGS countries & 3.52 & & 2.33 & & 2.72 & \\
\hline Non-PIIGS EMU countries & 1.27 & & 1.2 & & 1.51 & \\
\hline
\end{tabular}


Table 2 Industry and Country Effects -Value Weighted (Continued)

\begin{tabular}{lcccccc}
\hline Panel B: Non-Euro countries & \multicolumn{2}{c}{$1992: 9$} & $-1998: 12$ & \multicolumn{2}{c}{$1999: 1-2007: 12$} & \multicolumn{2}{c}{$2008: 1-2011: 9$} \\
\hline Industry Effects & Mean & SD & Mean & SD & Mean & SD \\
\hline Basic Materials & -0.45 & 2.63 & 0.43 & 3.16 & 0.73 & 4.54 \\
Consumer Goods & -0.34 & 1.48 & 0.07 & 2.44 & 0.01 & 2.46 \\
Consumer Services & 0.5 & 1.52 & -0.23 & 1.86 & -0.59 & 2.02 \\
Financials & -0.01 & 1.36 & -0.12 & 1.79 & -0.29 & 1.96 \\
Health Care & -0.09 & 2.53 & 0.09 & 2.83 & -0.11 & 2.12 \\
Industrials & -0.12 & 1.6 & 0.07 & 1.91 & -0.34 & 1.35 \\
Oil \& Gas & -0.59 & 3.55 & 0.88 & 4.48 & 1.43 & 6.42 \\
Technology & 0.68 & 2.93 & 0.29 & 6.61 & 0.62 & 2.02 \\
Telecommunications & 0.68 & 6.11 & -0.74 & 6.11 & 0.29 & 4.22 \\
Utilities & 0.32 & 2.93 & 0.09 & 3.91 & -1.28 & 4.61 \\
\hline Average absolute industry effect & 1.81 & & 2.14 & & 2.15 & \\
\hline & & & & & & \\
\hline Country Effects & Mean & SD & Mean & SD & Mean & SD \\
\hline Denmark & -0.1 & 3.36 & 0.58 & 3.18 & -1.89 & 3.86 \\
Sweden & 0.61 & 5.24 & 0.4 & 3.91 & -0.5 & 3.95 \\
Switzerland & 0.15 & 2.94 & -0.17 & 1.96 & 0.78 & 3.82 \\
UK & -0.13 & 0.94 & 0.01 & 0.9 & -0.08 & 1.74 \\
\hline Average absolute country effect & 1.25 & & 1.11 & & 1.87 & \\
\hline Neragenny
\end{tabular}

Note: This table provides the mean and standard deviation (SD) of the industry and country effects in percentage per month for both Euro zone and non-Euro zone countries across three periods. The first period denotes the pre-Euro period from September 1992 to December 1998. The second period denotes post-Euro period before crisis from January 1999 to December 2007 and the third period denotes post-Euro crisis period from January 2008 to September 2011. PIIGS countries are made up of Portugal, Ireland, Italy, Greece and Spain. 
Table 3 Decomposition of Monthly Index Returns into Country and Industry Effects -Value Weighted

\begin{tabular}{|c|c|c|c|c|c|c|c|c|c|c|c|c|c|}
\hline \multirow{2}{*}{ Euro } & \multicolumn{2}{|c|}{ 1992:9-1998:12 } & \multicolumn{2}{|c|}{ 1999:1-2007:12 } & \multicolumn{2}{|c|}{ 2008:1-2011:9 } & \multirow{2}{*}{ Non-Euro } & \multicolumn{2}{|c|}{ 1992:9-1998:12 } & \multicolumn{2}{|c|}{ 1999:1-2007:12 } & \multicolumn{2}{|c|}{ 2008:1-2011:9 } \\
\hline & pure & sum & pure & sum & pure & sum & & pure & sum & pure & sum & pure & sum \\
\hline \multicolumn{14}{|l|}{ Panel A: Country } \\
\hline Austria & 3.15 & 0.88 & 2.40 & 2.22 & 2.29 & 0.74 & Denmark & 3.36 & 0.87 & 3.18 & 0.98 & 3.86 & 0.71 \\
\hline Belgium & 1.96 & 0.67 & 2.75 & 1.96 & 2.26 & 1.08 & Sweden & 5.24 & 1.21 & 3.91 & 1.77 & 3.95 & 0.81 \\
\hline Finland & 5.98 & 1.42 & 3.71 & 3.91 & 2.77 & 0.78 & Switzerland & 2.94 & 0.88 & 1.96 & 0.96 & 3.82 & 0.95 \\
\hline France & 1.60 & 0.39 & 1.70 & 1.02 & 1.63 & 0.24 & UK & 0.94 & 0.31 & 0.90 & 0.32 & 1.74 & 0.53 \\
\hline Germany & 1.54 & 0.65 & 2.03 & 1.20 & 2.33 & 0.31 & & & & & & & \\
\hline Greece & 5.90 & 0.96 & 7.92 & 1.32 & 5.40 & 0.55 & & & & & & & \\
\hline Ireland & 3.64 & 0.69 & 3.22 & 2.29 & 5.51 & 0.99 & & & & & & & \\
\hline Italy & 5.43 & 1.36 & 2.83 & 1.55 & 2.01 & 0.66 & & & & & & & \\
\hline Luxembourg & 2.56 & 1.33 & 3.15 & 3.86 & 2.91 & 1.34 & & & & & & & \\
\hline Netherland & 1.69 & 1.45 & 1.95 & 1.41 & 2.94 & 0.84 & & & & & & & \\
\hline Portugal & 3.94 & 0.92 & 4.11 & 4.45 & 3.50 & 0.73 & & & & & & & \\
\hline Spain & 4.46 & 0.84 & 2.70 & 3.08 & 2.21 & 0.97 & & & & & & & \\
\hline \multicolumn{14}{|l|}{ Panel B: Industry } \\
\hline $\mathrm{BM}$ & 1.72 & 0.71 & 3.30 & 0.80 & 2.93 & 1.11 & $\mathrm{BM}$ & 2.63 & 0.54 & 3.16 & 0.39 & 4.54 & 0.99 \\
\hline CG & 1.03 & 0.62 & 3.49 & 0.48 & 2.12 & 0.50 & CG & 1.48 & 0.32 & 2.44 & 0.39 & 2.46 & 0.67 \\
\hline CS & 1.20 & 0.70 & 2.40 & 0.51 & 2.37 & 0.36 & CS & 1.52 & 0.81 & 1.86 & 0.65 & 2.02 & 1.37 \\
\hline FI & 1.14 & 0.54 & 2.90 & 0.42 & 1.51 & 0.31 & FI & 1.36 & 0.66 & 1.79 & 0.28 & 1.96 & 0.21 \\
\hline $\mathrm{HC}$ & 1.40 & 0.89 & 2.80 & 0.98 & 1.51 & 0.64 & $\mathrm{HC}$ & 2.53 & 1.04 & 2.83 & 0.68 & 2.12 & 1.57 \\
\hline IN & 2.12 & 0.33 & 3.57 & 0.30 & 1.87 & 0.21 & IN & 1.60 & 0.66 & 1.91 & 0.62 & 1.35 & 0.79 \\
\hline OG & 5.08 & 1.36 & 4.53 & 0.82 & 3.14 & 0.65 & OG & 3.55 & 0.94 & 4.48 & 0.86 & 6.42 & 1.59 \\
\hline TEC & 3.37 & 1.18 & 5.66 & 1.62 & 2.35 & 0.83 & TEC & 2.93 & 2.69 & 6.61 & 1.86 & 2.02 & 1.48 \\
\hline TEL & 4.19 & 2.89 & 7.67 & 0.57 & 7.19 & 0.57 & TEL & 6.11 & 0.88 & 6.11 & 0.43 & 4.22 & 0.97 \\
\hline UT & 2.40 & 1.47 & 3.63 & 1.12 & 5.12 & 0.54 & UT & 2.93 & 0.71 & 3.91 & 0.73 & 4.61 & 0.73 \\
\hline \multicolumn{14}{|l|}{ Panel C: Averages } \\
\hline Cross-country & 3.49 & 0.96 & 3.21 & 2.36 & 2.98 & 0.77 & Cross-country & 3.12 & 0.82 & 2.49 & 1.01 & 3.35 & 0.75 \\
\hline Cross-industry & 2.37 & 1.07 & 5.68 & 0.76 & 4.00 & 0.76 & Cross-industry & 2.67 & 0.93 & 3.51 & 0.69 & 3.17 & 1.04 \\
\hline Common Factor & 3.40 & & 4.89 & & 5.88 & & Common Factor & 4.16 & & 4.76 & & 6.15 & \\
\hline Country/Industry & 1.47 & 0.90 & 0.56 & 3.08 & 0.80 & 3.09 & Country/Industry & 1.17 & 0.88 & 0.71 & 1.46 & 1.06 & 0.72 \\
\hline Country/Common & 1.03 & & 0.66 & & 0.51 & & Country/Common & 0.75 & & 0.52 & & 0.54 & \\
\hline
\end{tabular}

Note: This table presents the time series variance of the components resulting from the decomposition of country (industry) returns into a common factor, a pure country (industry) factor and an average of the industry (country) factors for the value-weighted Euro zone equity market. In Panel A (B) each country (industry) index return is decomposed into a pure country (industry) effect and a sum of 10 industry (12 country) effects. The pure country (industry) effect 
measures the average return of firms in a country (industry) relative to firms which are in the same industry (country) but located in a different country (industry). The sum of the industry (country) effects represents the component of a country's (an industry's) return that can be attributed to the difference between the industrial (geographical) composition of its index and the industrial (geographical) composition of the European market. Returns are measured in percentage per month. See note to Table 1 for abbreviations of industry sectors.. 
Table 4 Tests for Multiple Breaks at Unknown Points in the Sample Mean Based on Bai and Perron (1998, 2003)

\begin{tabular}{|c|c|c|c|c|c|}
\hline \multirow[b]{2}{*}{ Series } & \multicolumn{5}{|c|}{ Double maximum tests } \\
\hline & \multicolumn{3}{|c|}{ UDmax } & \multicolumn{2}{|c|}{ WDmax } \\
\hline \multirow[t]{3}{*}{$M A D_{C O N} / M A D_{I N D}$} & \multicolumn{3}{|c|}{20.87} & \multicolumn{2}{|c|}{23.94} \\
\hline & \multicolumn{5}{|c|}{ sup $-F(l \mid l+1)$ test statistics } \\
\hline & $\mathrm{F}(2 \mid 1)$ & $\mathrm{F}(3 \mid 2)$ & $\mathrm{F}(4 \mid 3)$ & $\begin{array}{r}\text { Estimated br } \\
\text { confide }\end{array}$ & $\begin{array}{l}\text { ates and 95\% } \\
\text { ntervals }\end{array}$ \\
\hline \multirow[t]{3}{*}{$M A D_{C O N} / M A D_{I N D}$} & 13.15 & 11.07 & 8.23 & $\begin{array}{c}1998: 8[1 \\
2007: 9[2\end{array}$ & $\begin{array}{c}\text {; 1998:11] } \\
\text { 5; 2008:3] }\end{array}$ \\
\hline & \multicolumn{5}{|c|}{ Estimated mean of $M A D_{C O N} / M A D_{I N D}$ by sub-sample } \\
\hline & & 1992:9-1999:8 & & 1999:11-2007:9 & 2007:10-2011:9 \\
\hline$M A D_{C O N} / M A D_{I N D}$ & & $\begin{array}{l}1.42 * \\
(0.02)\end{array}$ & & $\begin{array}{c}0.85^{*} \\
(0.02)\end{array}$ & $\begin{array}{c}1.14^{*} \\
(0.03)\end{array}$ \\
\hline
\end{tabular}

Note: This table reports the results of the structural break test on the mean of the MAD ratio by using the approach suggested by Bai and Perron (1998, 2003). The critical values of UDmax and WDmax tests at the 5\% level are 8.88 and 9.91, respectively. The critical values of the sup $-F(l+1 \mid l)$ test at the $5 \%(10 \%)$ level are $10.13(8.51), 11.14(9.41)$ and $11.83(10.04)$ for $l=$ 1,2 and 3 respectively. * denotes significance at $1 \%$ level while figures in parenthesis are standard errors. 
Table 5 Summary Statistics of Macroeconomic Fundamentals

\begin{tabular}{|c|c|c|c|c|c|c|c|c|}
\hline \multirow{2}{*}{ Panel (A) } & \multicolumn{2}{|c|}{ Euro } & \multicolumn{2}{|c|}{ Non-Euro } & \multicolumn{2}{|c|}{ PIIGS } & \multicolumn{2}{|c|}{ Non-PIIGS } \\
\hline & Mean & SD & Mean & SD & Mean & SD & Mean & SD \\
\hline \multicolumn{9}{|c|}{ Sample (I): 2000-2011 } \\
\hline Debt/GDP & 65.55 & 30.59 & 41.98 & 13.45 & 78.45 & 35.66 & 53.46 & 23.66 \\
\hline GDP growth & 0.291 & 4.308 & 0.296 & 5.133 & 0.302 & 4.490 & 0.289 & 4.543 \\
\hline Inflation & 2.541 & 3.311 & 2.709 & 1.952 & 2.954 & 3.441 & 2.216 & 3.081 \\
\hline CA/GDP & -0.152 & 6.721 & 3.769 & 4.711 & -4.683 & 4.618 & 2.667 & 5.999 \\
\hline Corruption & 7.203 & 1.529 & 8.959 & 0.514 & 5.816 & 1.405 & 8.250 & 1.029 \\
\hline 5Yr bond & 3.910 & 2.126 & 3.422 & 1.303 & 4.423 & 2.913 & 3.522 & 1.317 \\
\hline \multicolumn{9}{|c|}{ Sample (II): 2000-2007 } \\
\hline Debt/GDP & 61.93 & 29.29 & 40.39 & 11.88 & 72.32 & 33.73 & 51.37 & 23.19 \\
\hline GDP growth & 0.609 & 4.202 & 0.611 & 5.228 & 0.716 & 4.351 & 0.575 & 4.521 \\
\hline Inflation & 2.837 & 3.311 & 1.937 & 2.522 & 3.519 & 3.431 & 2.330 & 3.023 \\
\hline CA/GDP & 0.276 & 6.674 & 2.995 & 4.149 & -4.212 & 4.382 & 2.715 & 5.865 \\
\hline Corruption & 7.278 & 1.475 & 9.041 & 0.406 & 5.944 & 1.267 & 8.310 & 1.036 \\
\hline 5Yr bond & 3.818 & 0.808 & 3.891 & 1.124 & 3.849 & 0.879 & 3.844 & 0.921 \\
\hline \multicolumn{9}{|c|}{ Sample (III): 2008-2011 } \\
\hline Debt/GDP & 73.21 & 31.93 & 45.39 & 15.88 & 91.21 & 36.45 & 57.94 & 24.11 \\
\hline GDP growth & -0.399 & 4.466 & -0.375 & 4.900 & -0.619 & 4.693 & -0.321 & 4.540 \\
\hline Inflation & 1.909 & 3.232 & 1.978 & 3.038 & 1.749 & 3.165 & 1.985 & 3.189 \\
\hline CA/GDP & -1.046 & 6.751 & 5.163 & 5.339 & -5.69 & 4.972 & 2.571 & 6.274 \\
\hline Corruption & 7.043 & 1.633 & 8.785 & 0.662 & 5.543 & 1.639 & 8.124 & 1.006 \\
\hline 5Yr bond & 4.090 & 3.466 & 2.421 & 1.082 & 5.65 & 4.794 & 2.916 & 1.706 \\
\hline Panel (B) & $\begin{array}{c}\text { Country } \\
\text { effect }\end{array}$ & Debt/GDP & $\begin{array}{l}\text { GDP } \\
\text { growth }\end{array}$ & Inflation & CA/GDP & Corruption & $\begin{array}{l}5 \mathrm{Yr} \\
\text { bond }\end{array}$ & $\begin{array}{c}\text { S\&P500 } \\
\text { rating }\end{array}$ \\
\hline Debt/GDP & $-0.117 *$ & & & & & & & \\
\hline GDP growth & 0.026 & -0.018 & & & & & & \\
\hline Inflation & -0.057 & 0.014 & $-0.13^{*}$ & & & & & \\
\hline CA/GDP & $0.097^{*}$ & $-0.446 *$ & 0.020 & 0.08 & & & & \\
\hline Corruption & $0.155^{*}$ & $-0.729 *$ & 0.014 & $-0.104 *$ & $0.665^{*}$ & & & \\
\hline 5Yr bond & $-0.116^{*}$ & $0.311^{*}$ & 0.010 & $0.149 *$ & $-0.259 *$ & $-0.265 *$ & & \\
\hline S\&P500 rating & $0.192 *$ & $-0.702 *$ & 0.008 & $-0.094 *$ & $0.585^{*}$ & $0.804^{*}$ & $-0.44^{*}$ & \\
\hline Fitch rating & $0.186^{*}$ & $-0.723 *$ & 0.003 & $-0.084 *$ & $0.499 *$ & $0.731^{*}$ & $-0.61 *$ & $0.89 *$ \\
\hline
\end{tabular}

Note: This table provides the summary statistics of the regressors in Panel (A). Panel (B) shows the correlation matrix of these macroeconomic variables and country effect. * denotes statistical significance at the $5 \%$ level. 
Table 6 Fixed Effect Regressions of the Determinants of Country Effects in Euro Area

\begin{tabular}{|c|c|c|c|c|c|c|c|c|c|c|}
\hline & \multirow[b]{2}{*}{ Const } & \multirow[b]{2}{*}{ D2 } & \multicolumn{8}{|c|}{ Interacted with D1 } \\
\hline & & & $\begin{array}{l}\text { Debt/ } \\
\text { GDP }\end{array}$ & $\begin{array}{l}\text { GDP } \\
\text { growth }\end{array}$ & Inf & $\begin{array}{l}\text { CA/ } \\
\text { GDP }\end{array}$ & Corrupt & 5-yr bond & $\begin{array}{l}\text { S\&P } \\
500\end{array}$ & Fitch \\
\hline (1) & $\begin{array}{l}0.479 \\
(0.75)\end{array}$ & $\begin{array}{l}0.558 \\
(1.23)\end{array}$ & $\begin{array}{l}-0.009 \\
(-0.90)\end{array}$ & & & & & & & \\
\hline (2) & $\begin{array}{c}-0.11 \\
(-1.06)\end{array}$ & $\begin{array}{c}-0.411 \\
(-2.22)^{* *}\end{array}$ & & $\begin{array}{c}0.045 \\
(1.84)^{*}\end{array}$ & & & & & & \\
\hline (3) & $\begin{array}{l}0.055 \\
(0.40)\end{array}$ & $\begin{array}{c}-0.552 \\
(-2.48)^{* *}\end{array}$ & & & $\begin{array}{l}-0.052 \\
(-1.59)\end{array}$ & & & & & \\
\hline (4) & $\begin{array}{l}-0.050 \\
(-0.49)\end{array}$ & $\begin{array}{c}-0.421 \\
(-2.32)^{* *}\end{array}$ & & & & $\begin{array}{c}-0.050 \\
(-1.95)^{*}\end{array}$ & & & & \\
\hline (5) & $\begin{array}{l}-3.416 \\
(-1.61)\end{array}$ & $\begin{array}{c}-3.125 \\
(-3.57)^{* * *}\end{array}$ & & & & & $\begin{array}{l}0.456 \\
(1.57)\end{array}$ & & & \\
\hline (6) & $\begin{array}{c}-0.993 \\
(-1.74)^{*}\end{array}$ & $\begin{array}{l}-0.955 \\
(-1.53)\end{array}$ & & & & & & $\begin{array}{l}0.253 \\
(1.62)\end{array}$ & & \\
\hline (7) & $\begin{array}{l}1.465 \\
(0.62)\end{array}$ & $\begin{array}{c}-5.373 \\
(-4.10)^{* * *}\end{array}$ & & & & & & & $\begin{array}{c}-0.14 \\
(-0.66)\end{array}$ & \\
\hline (8) & $\begin{array}{l}2.962 \\
(1.14)\end{array}$ & $\begin{array}{c}-6.504 \\
(-3.31)^{* * *}\end{array}$ & & & & & & & & $\begin{array}{l}-0.179 \\
(-1.17)\end{array}$ \\
\hline (9) & $\begin{array}{l}-1.263 \\
(-1.26)\end{array}$ & $\begin{array}{c}-1.504 \\
(-1.76)^{*}\end{array}$ & $\begin{array}{l}0.0037 \\
(0.29)\end{array}$ & $\begin{array}{c}0.0332 \\
(1.21)\end{array}$ & $\begin{array}{c}-0.0366 \\
(-0.95)\end{array}$ & $\begin{array}{c}-0.0089 \\
(-0.25)\end{array}$ & & $\begin{array}{l}0.281 \\
(1.38)\end{array}$ & & \\
\hline (10) & $\begin{array}{c}-5.488 \\
(-2.09)^{* *}\end{array}$ & $\begin{array}{c}-0.418 \\
(-1.81)^{*}\end{array}$ & $\begin{array}{l}0.0339 \\
(1.24)\end{array}$ & $\begin{array}{c}-0.0322 \\
(-0.84)\end{array}$ & & & $\begin{array}{c}0.605 \\
(1.75)^{*}\end{array}$ & $\begin{array}{l}0.309 \\
(1.01)\end{array}$ & & \\
\hline (11) & $\begin{array}{l}0.159 \\
(0.06)\end{array}$ & $\begin{array}{c}-1.782 \\
(-1.86)^{*}\end{array}$ & & $\begin{array}{l}0.033 \\
(1.20)\end{array}$ & $\begin{array}{l}-0.035 \\
(-0.91)\end{array}$ & $\begin{array}{l}0.0037 \\
(0.11)\end{array}$ & & $\begin{array}{l}0.266 \\
(1.27)\end{array}$ & $\begin{array}{l}-0.102 \\
(-0.44)\end{array}$ & \\
\hline \multirow[t]{3}{*}{ (12) } & $\begin{array}{l}1.176 \\
(0.38) \\
\end{array}$ & $\begin{array}{c}-4.934 \\
(-1.92)^{*} \\
\end{array}$ & & $\begin{array}{l}0.037 \\
(1.51)\end{array}$ & $\begin{array}{l}-0.035 \\
(-1.10) \\
\end{array}$ & $\begin{array}{l}-0.036 \\
(-1.34) \\
\end{array}$ & & & & $\begin{array}{l}-0.067 \\
(-0.37) \\
\end{array}$ \\
\hline & & & & & & Intera & ted with D2 & & & \\
\hline & & & $\begin{array}{l}\text { Debt/ } \\
\text { GDP }\end{array}$ & $\begin{array}{l}\text { GDP } \\
\text { growth }\end{array}$ & Inf & $\begin{array}{l}\text { CA/ } \\
\text { GDP }\end{array}$ & Corrupt & $\begin{array}{l}5 \text {-yr } \\
\text { bond }\end{array}$ & $\begin{array}{c}\text { S\&P } \\
500\end{array}$ & Fitch \\
\hline (1) & & & $\begin{array}{c}-0.022 \\
(-2.30)^{* *}\end{array}$ & & & & & & & \\
\hline (2) & & & & $\begin{array}{c}-0.0035 \\
(-0.10)\end{array}$ & & & & & & \\
\hline (3) & & & & & $\begin{array}{l}-0.022 \\
(-0.46)\end{array}$ & & & & & \\
\hline (4) & & & & & & $\begin{array}{c}0.065 \\
(2.21)^{* *}\end{array}$ & & & & \\
\hline (5) & & & & & & & $\begin{array}{c}0.850 \\
(3.12)^{* * *}\end{array}$ & & & \\
\hline (6) & & & & & & & & $\begin{array}{c}-0.135 \\
(-2.78) \\
* * *\end{array}$ & & \\
\hline (7) & & & & & & & & & $\begin{array}{c}0.32 \\
(2.02)^{* *}\end{array}$ & \\
\hline (8) & & & & & & & & & & $\begin{array}{c}0.182 \\
(2.07)^{* *}\end{array}$ \\
\hline (9) & & & $\begin{array}{l}0.0017 \\
(0.14)\end{array}$ & $\begin{array}{l}0.0166 \\
(-0.48)\end{array}$ & $\begin{array}{c}-0.0169 \\
(-0.32)\end{array}$ & $\begin{array}{c}0.084 \\
(2.29)^{* *}\end{array}$ & & $\begin{array}{c}-0.206 \\
(-2.33)^{* *}\end{array}$ & & \\
\hline (10) & & & & $\begin{array}{c}-0.0088 \\
(-0.26)\end{array}$ & $\begin{array}{l}0.0076 \\
(0.15)\end{array}$ & & $\begin{array}{c}0.876 \\
(2.73)^{* * *}\end{array}$ & $\begin{array}{c}-0.208 \\
(-2.70)^{* * *}\end{array}$ & & \\
\hline (11) & & & & $\begin{array}{l}-0.014 \\
(-0.41)\end{array}$ & $\begin{array}{l}-0.011 \\
(-0.21)\end{array}$ & $\begin{array}{l}0.0539 \\
(1.32)\end{array}$ & & $\begin{array}{l}-0.146 \\
(1.65)^{*}\end{array}$ & $\begin{array}{l}0.163 \\
(0.81)\end{array}$ & \\
\hline (12) & & & & $\begin{array}{l}-0.006 \\
(-0.19)\end{array}$ & $\begin{array}{c}-0.0192 \\
(-0.41) \\
\end{array}$ & $\begin{array}{l}0.042 \\
(1.24)\end{array}$ & & & & $\begin{array}{c}0.198 \\
(1.80)^{*}\end{array}$ \\
\hline
\end{tabular}

Note: This table represents the fixed effect model of the determinants of country effect in Euro area specified in equation (6) of Section 4.3. The dependent variable is country factor return. Figures in parentheses are robust t-statistics. ***, ** and * indicate significance at the $1 \%, 5 \%$ and $10 \%$ levels, respectively. 
Figure 1 The Ratio of the Mean Absolute Deviation (MAD) of Country to Industry Effects This figure plots the ratio of the six-month moving average of the monthly country and industry mean absolute deviation (MAD) in pre-Euro, post-Euro and crisis periods.

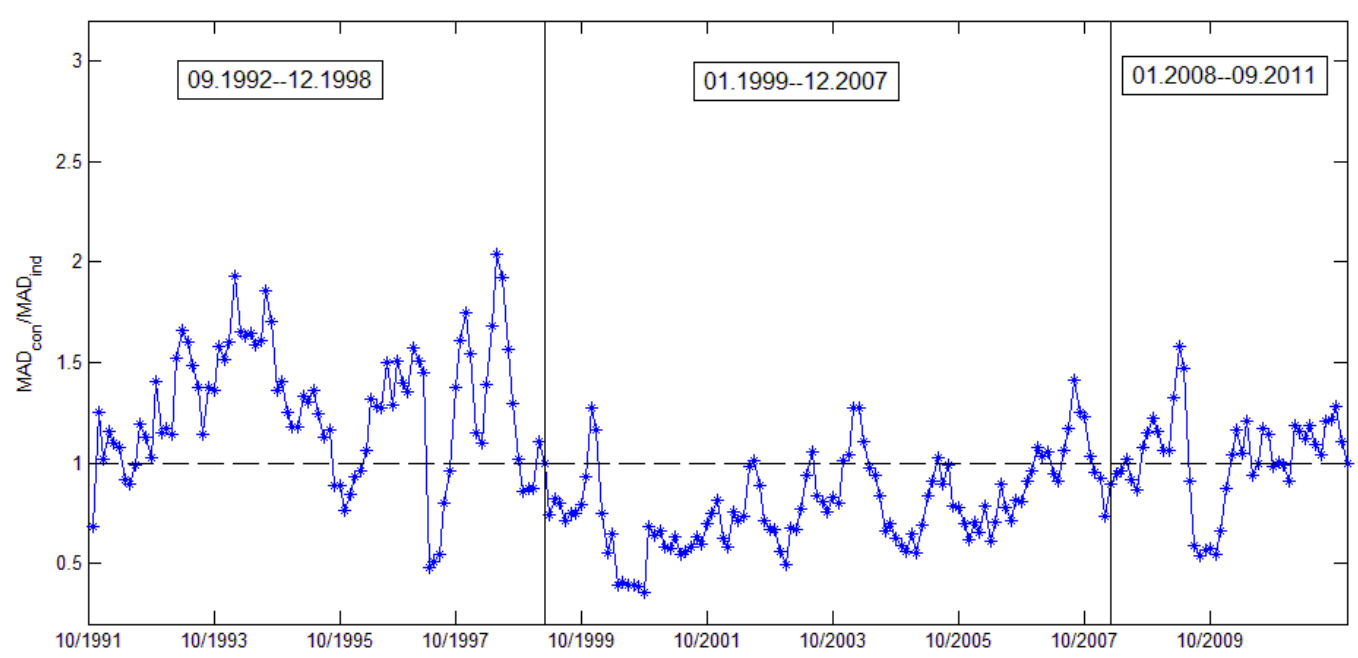


Figure 2 Structural Breaks for the MAD (6-month Moving Average) Ratio

This figure provides a visual impression of the structural break dates and the time-varying average MAD ratio across the sample period. The two break dates correspond to 1998:8 and 2007:9, and their corresponding confidence intervals are indicated by the symbol $|-|$ on the $\mathrm{x}$-axis. The estimated mean of the MAD ratio of country to industry effects are reported in Table 4.

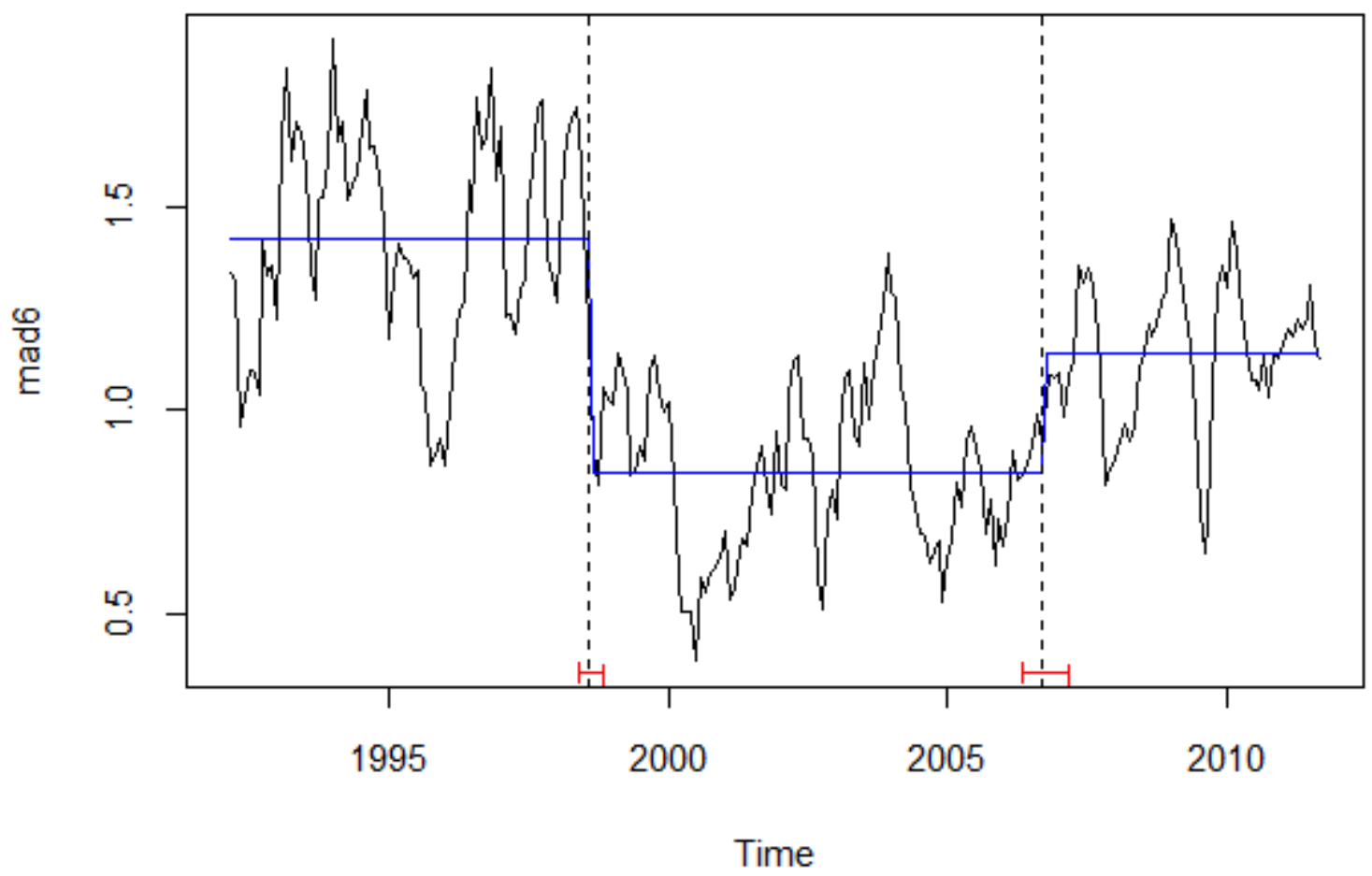




\section{Figure 3 Benefits of International Diversification against Number of Stocks}

This figure gives the portfolio variance as the number of stocks in the portfolio increases, expressed as a percentage of the variance of a typical stock in the pre-Euro, post-Euro and crisis periods, respectively. Industry (Country) strategy denotes a portfolio that diversifies across industries (countries) within a single country (industry). The unrestricted portfolio diversifies across both countries and industries.

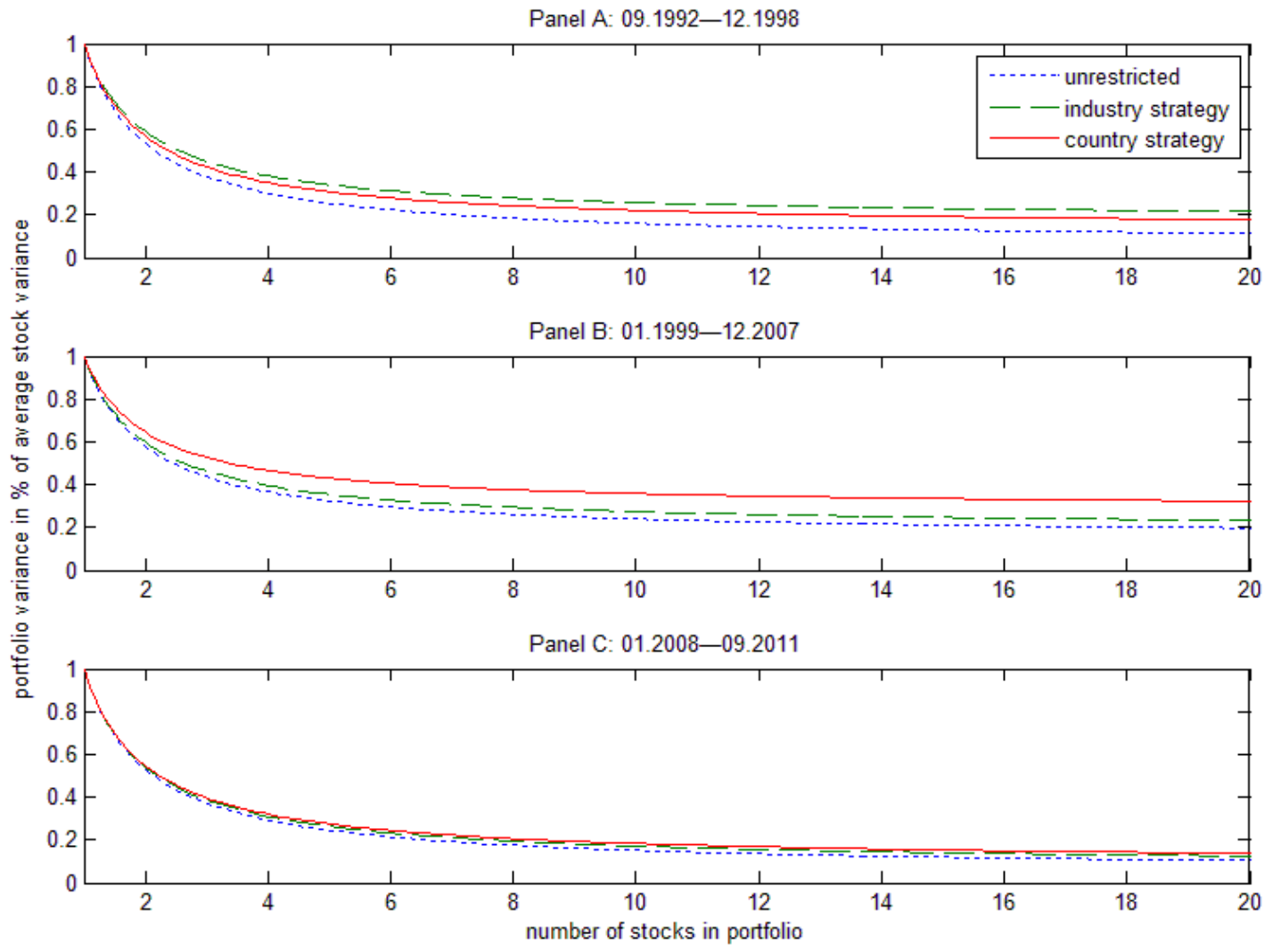




\section{References}

Abad, P., H. Chuliá, and M. Gómez-Puig (2010), "EMU and European Government Bond Market Integration”, Journal of Banking and Finance, 34, 2851-2860.

Baca, S.P., B.L. Garbe, R.A. Weiss (2000), “The Rise of Sector Effects in Major Equity Markets”, Financial Analysts Journal, 56, 34-40.

Bai, Y. and C. Green (2010). "International Diversification Strategies: Revisited from the Risk Perspective”, Journal of Banking and Finance, 34, 236-245.

Bai, J. and P. Perron (1998), "Estimating and Testing Linear Models with Multiple Structural Changes”, Econometrica, 66, 47-78.

Bai, J. and P. Perron (2003), “Conputation and Analysis of Multiple Structural Change Models”, Journal of Applied Econometrics, 18, 1-22.

Bartram, S., S. Taylor, and Y. Wang (2007). “The Euro and European Financial Market Integration”, Journal of Banking and Finance, 31, 1461-1481.

Brooks, R. and M. Del Negro (2006), "Firm-level Evidence on International Stock Market CoMovement”, Review of Finance, 10, 69-98.

Campa, J.M. and N. Fernandes. (2006), "Sources of gains from international portfolio diversification”, Journal of Empirical Finance, 13, 417-443.

Cavaglia, S., C. Brightman, M. Aked (2000), “The increasing Importance of Industry Factors", Financial Analysts Journal, 56, 41-54.

Eiling, E., B. Gerard and F.A. De Roon (2011), “Euro-zone equity returns: Country versus Industry Effects”, Review of Finance, in press.

Ferreira, M.A. and M.A. Ferreira (2006), “The Importance of Industry and Country Effects in the EMU Equity Markets”, European Financial Management, 12, 341-373.

Flavin, Thomas J. "The Effect of the Euro on Country versus Industry Portfolio Diversification”, Journal of International Money and Finance, 23 (2004), 1137-1158.

Goetzmann, W., Li. L, and G.K. Rouwenhorst (2002), “Long-term global market correlations”. Working Paper no. 8612, National Bureau of Economic Research, Cambridge, MA.

Griffin, J.M. and A.G. Karolyi (1998), “Another Look at the Role of the Industrial Structure of Markets for International Diversification Strategies”, Journal of Financial Economics, 50, 351-73.

Griffin, J.M. and R.M. Stulz (2001), "International Competition and Exchange Rate Shocks: A Cross-Country Industry Analysis of Stock Returns”, Review of Financial Studies, 14, 215-241. 
Heston, S.L. and G.K. Rouwenhorst (1994), "Does Industrial Structure Explain the Benefits of International Diversification?”, Journal of Financial Economics, 36, 3-27.

Heston, S.L. and G.K. Rouwenhorst (1995), "Industry and country effects in international stock returns”, Journal of Portfolio Management, 21, 53-58.

Kim, S.J., F. Moshirian, and E. Wu (2005). "Dynamic Stock Market Integration Driven by the European Monetary Union: An Empirical Analysis”, Journal of Banking and Finance, 29, 24752502.

Moerman, G. A. (2008), "Diversification in euro area stock markets: Country versus industry", Journal of International Money and Finance, 27, 1122-1134.

Morana, C. and A. Beltratti (2002). "The Effects of the Introduction of the Euro on the Volatility of European Stock Markets”, Journal of Banking and Finance, 26, 2047-2064.

Mylonidis, N. and C. Kollias (2010). "Dynamic European Stock Market Convergence: Evidence from Rolling Cointegration Analysis in the First Euro-decade”, Journal of Banking and Finance, 34, 2056-2064.

Phylaktis, K. and L. Xia (2006), “Sources of firms' industry and country effects in emerging markets”, Journal of International Money and Finance, 25, 459-475.

Reinhart, C., K. Rogoff, and M. Savastano (2003),“Debt Intolerance”, Brookings Papers on Economic Activity, January.

Rouwenhorst, G.K. (1999), “European Equity Markets and the EMU”, Financial Analysts Journal, 55, 57-64.

Wang, C., C. Lee, B. Huang (2003), "An analysis of industry and country effects in global stock returns: evidence from Asian countries and the US”, Quarterly Review of Economics and Finance, 43, 560-577. 


\section{Appendix: The double maximum tests and sequential structural break test of Bai and Perron $(1998,2003)$}

Following Bai and Perron (1998), the linear regression for analysing $m$ breaks is

$$
y_{t}=x_{t}^{\prime} \beta+z_{t}^{\prime} \delta_{j}+u_{t}, \quad t=T_{j-1}+1, \ldots, T_{j},
$$

for $j=1, \ldots, m+1$. Here, $y_{t}$ is the MAD ratio at time $t$ while both $x_{t}(p \times 1)$ and $z_{t}(q \times 1)$ are vectors of covariates and $\beta$ and $\delta_{j}(j=1, \ldots, m+1)$ are the corresponding vectors of coefficients; $u_{t}$ is the disturbance at time $t$. The indices $T_{1}, \ldots, T_{m}$ or break points are treated as unknown. The objective is to estimate the unknown regression coefficients together with the break points when $\mathrm{T}$ observations are available. In our case, $p=0$ since we only allow the mean to change in some periods. Using the estimation method of least squares, for each m-partition $\left(T_{1}, \ldots, T_{m}\right)$, the associated least equares estimates of $\beta$ and $\delta_{j}$ are obtained by minimizing the sum of squared residuals $S_{T}\left(T_{1}, \ldots, T_{m}\right)=\sum_{i=1}^{m+1} \sum_{t=T_{i-1}+1}^{T_{i}}\left[y_{t}-x_{t}^{\prime} \beta-z_{t}^{\prime} \delta_{j}\right]^{2}$. The estimated break points are such that $\left(\widehat{T}_{1}, \ldots, \widehat{T}_{m}\right)=\operatorname{argmin}_{\left(T_{1}, \ldots, T_{m}\right)} S_{T}\left(T_{1}, \ldots, T_{m}\right)$.

The Wald test for testing the null hypothesis of no change versus the alternative hypothesis of $k$ changes is given by

$$
W_{T}\left(\lambda_{1}, \ldots, \lambda_{k} ; q\right)=\left(\frac{T-(k+1) q-p}{k}\right) \frac{\hat{\delta}^{\prime} H^{\prime}\left(H\left(\bar{Z}^{\prime} M_{X} \bar{Z}\right)^{-1} H^{\prime}\right)^{-1} H \hat{\delta}}{S S R_{k}}
$$

where $H$ is now the matrix such that $(H \delta)^{\prime}=\left(\delta_{1}^{\prime}-\delta_{2}^{\prime}, \ldots, \delta_{k}^{\prime}-\delta_{k+1}^{\prime}\right), \overline{\mathrm{Z}}$ is the matrix which diagonally partitions $\mathrm{Z}$ at $\left(T_{1}, \ldots, T_{m}\right)$ such that $\overline{\mathrm{Z}}=\operatorname{diag}\left(\mathrm{Z}_{1}, \ldots, \mathrm{Z}_{\mathrm{m}+1}\right)$ with $Z_{i}=\left(z_{T_{i-1}+1}, \ldots, z_{T_{i}}\right)^{\prime}$, and $M_{X}=I-X\left(X^{\prime} X\right)^{-1} X^{\prime}$. Here $S S R_{k}$ is the sum of squared residuals under the alternative hypothesis, which depends on $\left(T_{1}, \ldots, T_{m}\right)$. The Sup-W test is defined by

$$
\sup _{\left(\lambda_{1}, \ldots, \lambda_{k}\right) \epsilon \Lambda_{\mathrm{k}, \varepsilon}} W_{T}\left(\lambda_{1}, \ldots, \lambda_{k} ; q\right)=W_{T}\left(\hat{\lambda}_{1}, \ldots, \hat{\lambda}_{k} ; q\right)
$$


where $\left(\hat{\lambda}_{1}, \ldots, \hat{\lambda}_{k}\right)=\left(\widehat{T}_{1} / T, \ldots, \widehat{T}_{k} / T\right)$ with $\left(\widehat{T}_{1}, \ldots, \widehat{T}_{m}\right)$ the estimates of the break dates obtained by minimizing the sum of squared residuals by searching over partitions defined by the set $\Lambda_{\varepsilon}$ defined as $\Lambda_{\varepsilon}=\left\{\left(\lambda_{1}, \ldots, \lambda_{k}\right) ;\left|\lambda_{i+1}-\lambda_{i}\right| \geq \varepsilon, \lambda_{1} \geq \varepsilon, \lambda_{k} \leq 1-\varepsilon\right\}$.

The equal-weight version of the'double maximum tests' is defined by $\operatorname{UDmax} W_{T}(M, q)=\max _{1 \leq m \leq M} W_{T}\left(\hat{\lambda}_{1}, \ldots, \hat{\lambda}_{k}, \ldots, \hat{\lambda}_{k} ; q\right)$ where $\hat{\lambda}_{j}=\widehat{T}_{j} / T$ for $j=1, \ldots, m$, in which these are the estimates of the break points obtained using the global minimization of the sum of squared residuals. The second test applies weights to the individual tests such that the marginal pvalues are equal across values of $m$ and is denoted $\operatorname{WDmax}_{T}(M, q)$ (see Bai and Perron, 1998, for details).

The sequential structural break test is defined by

$$
W_{T}(l+1 \mid l)=\frac{1}{\hat{\sigma}^{2}}\left\{S_{T}\left(\widehat{T}_{1}, \ldots, \widehat{T}_{l}\right)-\min _{1 \leq i \leq l+1 \tau \epsilon \Lambda_{\mathrm{i}, \varepsilon}} S_{T}\left(\widehat{T}_{1}, \ldots, \widehat{T}_{i-1}, \tau, \widehat{T}_{i}, \ldots, \widehat{T}_{l}\right)\right\}
$$

where $S_{T}($.$) denotes the sum of squared residuals and \hat{\sigma}^{2}$ is a consistent estimate of $\sigma^{2}$ under the null hypothesis. 